\title{
Arthrobacter nitroguajacolicus sp. nov., a novel 4-nitroguaiacol-degrading actinobacterium
}

Correspondence

Ludmila Kotoučková

lida@sci.muni.cz

\author{
Ludmila Kotoučková, ${ }^{1}$ Peter Schumann, ${ }^{2}$ Eva Durnová, ${ }^{3}$ Cathrin Spröer, ${ }^{2}$ \\ Ivo Sedláček, ${ }^{4}$ Jiří Neča, ${ }^{5}$ Zbyněk Zdráhal ${ }^{6,7}$ and Miroslav Němec ${ }^{1}$ \\ ${ }^{1}$ Department of Microbiology, Faculty of Science, Masaryk University Brno, Tvrdého 14,
} \author{
60200 Brno, Czech Republic \\ ${ }^{2} \mathrm{DSMZ}$ - German Collection of Microorganisms and Cell Cultures, Braunschweig, Germany \\ ${ }^{3}$ Regional Institute of Public Health, Ostrava, Czech Republic \\ ${ }^{4} \mathrm{CCM}$ - Czech Collection of Microorganisms, Masaryk University Brno, Czech Republic \\ ${ }^{5}$ Veterinary Research Institute, Brno, Czech Republic \\ ${ }^{6}$ Institute of Analytical Chemistry, Brno, Czech Republic \\ ${ }^{7}$ Laboratory of Functional Genomics and Proteomics, Faculty of Science, Masaryk University \\ Brno, Czech Republic
}

\begin{abstract}
Three bacterial isolates from soil, capable of degradation or transformation of nitroaromatic compounds and displaying a rod-coccus growth cycle, were studied by a polyphasic approach. On the basis of 16S rRNA sequence analysis and of chemotaxonomic characteristics, such as type $A 3 \alpha$ peptidoglycan with an interpeptide bridge Ala-Thr-Ala, the major menaquinone MK-9 $\left(\mathrm{H}_{2}\right)$ and fatty acid composition, the isolates were assigned to the genus Arthrobacter. DNA-DNA hybridization, riboprinting and phenotypic studies revealed that the three strains constitute a single species, distinct from phylogenetically neighbouring Arthrobacter aurescens and Arthrobacter ilicis. A novel species, Arthrobacter nitroguajacolicus sp. nov., with the type strain $\mathrm{G} 2-1^{\top}\left(=\mathrm{CCM} 4924^{\top}=\mathrm{DSM} 15232^{\top}\right)$ is proposed.
\end{abstract}

The genus Arthrobacter (Conn \& Dimmick, 1947; Koch et al., 1995) embraces more than 30 species of bacteria isolated mostly from soil. Arthrobacters are metabolically versatile, and some species of this genus are characterized by the ability to metabolize xenobiotics (Westerberg et al., 2000). Strain 8/3 (=CCM 4925=DSM 15233), identified at first as Corynebacterium sp., was isolated from contaminated soil (Kotoučková et al., 1997) and showed the ability to degrade nitroaromatic compounds. Two additional strains, G2- $1^{\mathrm{T}}$ and P1P (= CCM $7049=\mathrm{DSM} 15234$ ), capable of degrading 4-nitroguaiacol (4-NG), were later isolated from forest soil.

For isolation, approximately $1 \mathrm{~g}$ soil was transferred into $100 \mathrm{ml}$ mineral medium (MM) supplemented with $0 \cdot 1 \mathrm{mM}$ 4-nitrophenol (4-NP), and incubated at $28{ }^{\circ} \mathrm{C}$ on a rotary

Published online ahead of print on 28 November 2003 as DOI 10.1099/ijs.0.02923-0.

Abbreviations: 4-NG, 4-nitroguaiacol; 4-NP, 4-nitrophenol.

The GenBank/EMBL/DDBJ accession number for the $16 \mathrm{~S}$ rDNA sequence of strain $\mathrm{G} 2-1^{\top}$ is AJ512504.

Tables showing the differentiating physiological reactions and cellular fatty acid composition of Arthrobacter nitroguajacolicus sp. nov. strains are available as supplementary material in IJSEM Online. shaker. The composition of $\mathrm{MM}\left(\mathrm{g}^{-1}\right)$ was as follows: $\mathrm{CaCl}_{2}, \quad 0.0275 ; \quad \mathrm{MgSO}_{4} .7 \mathrm{H}_{2} \mathrm{O}, \quad 0.0225 ; \quad \mathrm{FeCl}_{3} .6 \mathrm{H}_{2} \mathrm{O}$, 0.00025; $\left(\mathrm{NH}_{4}\right)_{2} \mathrm{SO}_{4}, 0.05 ; \mathrm{KH}_{2} \mathrm{PO}_{4}, 0 \cdot 17 ; \mathrm{K}_{2} \mathrm{HPO}_{4}, 0 \cdot 42$; $\mathrm{Na}_{2} \mathrm{HPO}_{4} \cdot 12 \mathrm{H}_{2} \mathrm{O}, 0 \cdot 88$. The enrichment products $(10 \mathrm{ml})$ were transferred to $100 \mathrm{ml}$ fresh MM supplemented with 4-NP (strain P1P), or to MM supplemented with 4-NG (strain $\mathrm{G} 2-1^{\mathrm{T}}$ ). After degradation of the nitroaromatic compounds, indicated by decolorization of the medium, the procedure was repeated three times. Subsequent streaking on solid MM supplemented with 4-NP or 4-NG resulted in the formation of single colonies. Degradation of nitroaromatic compounds was confirmed by cultivation of the strains in liquid MM supplemented with 4-NP $\left(0.05 \mathrm{~g} \mathrm{l}^{-1}\right)$ or 4-NG $\left(0.004 \mathrm{~g} \mathrm{l}^{-1}\right)$, and by HPLC analysis. A Waters HPLC system, with a reverse-phase Nova-Pak C18 column and acetonitrile/0.1\% acetic acid $(15: 85)$ as the mobile phase, was used for HPLC analysis. Strain $8 / 3$ was cultivated in $\mathrm{MM}$ with $0.2 \%(\mathrm{w} / \mathrm{v})$ peptone and $0.05 \mathrm{~g} 4-\mathrm{NP}^{-1}$. Identification of $4-\mathrm{NG}$ as a product of 4-NP transformation by strain $8 / 3$ was performed with a liquid HP 1100 chromatograph (Hewlett-Packard) coupled with an ion trap mass spectrometer (Bruker Daltonik).

Nutrient agar (CM2, Oxoid) was used for the characterization of colonies and cell morphology. Cell size was 
determined by light microscopy with image analysis software (Laboratory Imaging). To observe cell shape during growth phases, scanning electron microscopy was employed: cells grown in nutrient broth (Oxoid) were fixed with $3 \%(\mathrm{v} / \mathrm{v})$ glutaraldehyde in $0 \cdot 1 \mathrm{M}$ cacodylate buffer, $\mathrm{pH} 7 \cdot 2$, and dehydrated samples were coated with gold in a sputter-coater (Polaron) and examined with a Philips CM12/STEM electron microscope (Pospísil et al., 1998). Images were stored digitally (AnalySis 3.2 Pro, Soft Imaging System). Gram staining was examined as described previously (Smibert \& Krieg, 1994). Motility was determined by the hanging drop method (Smibert \& Krieg, 1994). The physiological and biochemical characteristics of the strains grown on nutrient agar were studied as described previously (Smibert \& Krieg, 1994). The API CORYNE system was used for examination of isolates as a routine system, and API ZYM was chosen for additional enzymic characterization. The ability of strains to utilize a broad range of carbon sources was determined by using Biolog GP2 microplates (Biolog, Inc.). All commercial kits were used according to the manufacturers' instructions.

Cells for fatty acid analysis were harvested from $24 \mathrm{~h}$ cultures grown at $28{ }^{\circ} \mathrm{C}$ on Trypticase soy broth agar. Fatty acids were extracted and analysed following the instructions of the Microbial Identification System operating manual (MIDI, Inc., 1999). Peptidoglycan structure was determined using purified cell-wall hydrolysates, according to the method of Schleifer (1985). Amino acids and peptides were separated by two-dimensional ascending TLC on cellulose plates with the solvent systems of Schleifer \& Kandler (1972). The N-terminal amino acid of the interpeptide bridge was determined by dinitrophenylation as described by Schleifer (1985). Menaquinones were extracted according to Collins et al. (1977) and analysed by HPLC (Groth et al., 1996).

Genomic-DNA extraction, PCR-mediated amplification of the 16S rRNA and purification of PCR products were carried out as described previously (Rainey et al., 1996).

The ae2 editor (Maidak et al., 1999) was used to align the $16 \mathrm{~S}$ rRNA sequences obtained in this study with the $16 \mathrm{~S}$ rRNA sequences of representatives of the principal bacterial lineages available from public databases. Evolutionary distances were calculated by the method of Jukes \& Cantor (1969). Phylogenetic dendrograms were constructed using neighbour-joining algorithms (De Soete, 1983).

For determination of $\mathrm{G}+\mathrm{C}$ content and for DNA-DNA hybridization, DNA was isolated by breaking cells in a French press, followed by purification by hydroxyapatite chromatography (Cashion et al., 1977). G+C content was determined by reverse-phase HPLC of nucleosides (Mesbah et al., 1989). DNA-DNA reassociation was performed under optimal conditions $\left(2 \times\right.$ SSC at $\left.67^{\circ} \mathrm{C}\right)$ and recorded using a Gilford 2600 spectrophotometer (Huß et al., 1983; Jahnke, 1992). Automated ribotyping was carried out using the RiboPrinter microbial characterization system (Qualicon,
DuPont) and EcoRI and PvuII to generate restriction fragments. Band patterns were compared by BioNumerics software (Applied Maths). Clustering was performed by the unweighted pair group method with arithmetic means (UPGMA) based on Pearson's correlation coefficient, using an optimization coefficient of $1 \cdot 2 \%$.

An almost complete 16S rRNA gene sequence of $1488 \mathrm{nt}$ was determined for strain $\mathrm{G} 2-1^{\mathrm{T}}$, ranging from position 18 $\left(5^{\prime}\right)$ to $1526\left(3^{\prime}\right)$, following the Escherichia coli numbering of Brosius et al. (1978). Phylogenetic analyses, based on a dataset consisting of 1150 unambiguous nucleotides between positions 41 and 1158 , showed that strain G2-1 ${ }^{\mathrm{T}}$ belongs to the radiation of the genus Arthrobacter (Fig. 1). The highest binary 16S rRNA similarity value was found with Arthrobacter aurescens DSM $20116^{\mathrm{T}}(99 \cdot 7 \%)$ and Arthrobacter ilicis DSM $10138^{\mathrm{T}}(99 \cdot 1 \%)$. The DNA-DNA reassociation values between strain $\mathrm{G} 2-1^{\mathrm{T}}$ and its closest phylogenetic neighbours were $38 \cdot 4 \%$ (A. ilicis DSM $10138^{\mathrm{T}}$ ) and $44 \cdot 8 \%$ (A. aurescens DSM $20116^{\mathrm{T}}$ ), clearly below the $70 \%$ considered to be the threshhold value for the delineation of genomic species (Wayne et al., 1987). The DNA-DNA similarity of strains $\mathrm{G} 2-1^{\mathrm{T}}$ and $8 / 3$ was $78 \cdot 2 \%$ (repetition $81.5 \%$ ). The RiboPrint patterns of strains G2- $1^{\mathrm{T}}, 8 / 3$ and P1P were nearly identical and differed from those of the type strains of $A$. ilicis and A. aurescens (Fig. 2). The results of DNA-DNA hybridization and RiboPrint analyses indicated that strains $\mathrm{G} 2-1^{\mathrm{T}}, 8 / 3$ and $\mathrm{P} 1 \mathrm{P}$ constituted a homogeneous genomic species.

Colonies of strains G2-1 ${ }^{\mathrm{T}}$, P1P and 8/3 grown aerobically on nutrient agar were yellow-coloured, circular, convex and opaque. Cells were Gram-positive, irregular, nonspore-forming rods and displayed a rod-coccus life cycle (Fig. 3). Growth and physiological characteristics of the three strains are given in the species description and are also shown in Supplementary Table A in IJSEM Online. In addition, strains $\mathrm{G} 2-1^{\mathrm{T}}$ and P1P use 4-NG as a growth substrate, and strain $8 / 3$ produces $4-\mathrm{NG}$ in the course of 4-NP transformation. Characteristics that differentiate strain $\mathrm{G} 2-1^{\mathrm{T}}$ from the type strains of the phylogenetically related species A. aurescens and A. ilicis are summarized in Table 1.

The cell wall peptidoglycan of strains $\mathrm{G} 2-1^{\mathrm{T}}, 8 / 3$ and P1P contained lysine in position 3 of the peptide subunit and the interpeptide bridge, Ala-Thr-Ala. This polymer type is consistent with the types A3 $\alpha$ (Schleifer \& Kandler, 1972) and A11.17, according to the DSMZ catalogue of strains (DSMZ, 2001). Labelling by 1-fluoro-2,4-dinitrobenzene confirmed that alanine represents the $\mathrm{N}$ terminus of the interpeptide bridge.

The major menaquinone of strains $\mathrm{G} 2-1^{\mathrm{T}}, 8 / 3$ and $\mathrm{P} 1 \mathrm{P}$ was MK-9 $\left(\mathrm{H}_{2}\right)$. MK- $8\left(\mathrm{H}_{2}\right)$ and MK-10 $\left(\mathrm{H}_{2}\right)$ occurred as minor components. The peptidoglycan type and menaquinone pattern place strain G2-1 ${ }^{\mathrm{T}}$ in group II of Arthrobacter species along with Arthrobacter aurescens, Arthrobacter ilicis, Arthrobacter ureafaciens, Arthrobacter histidinolovorans and 


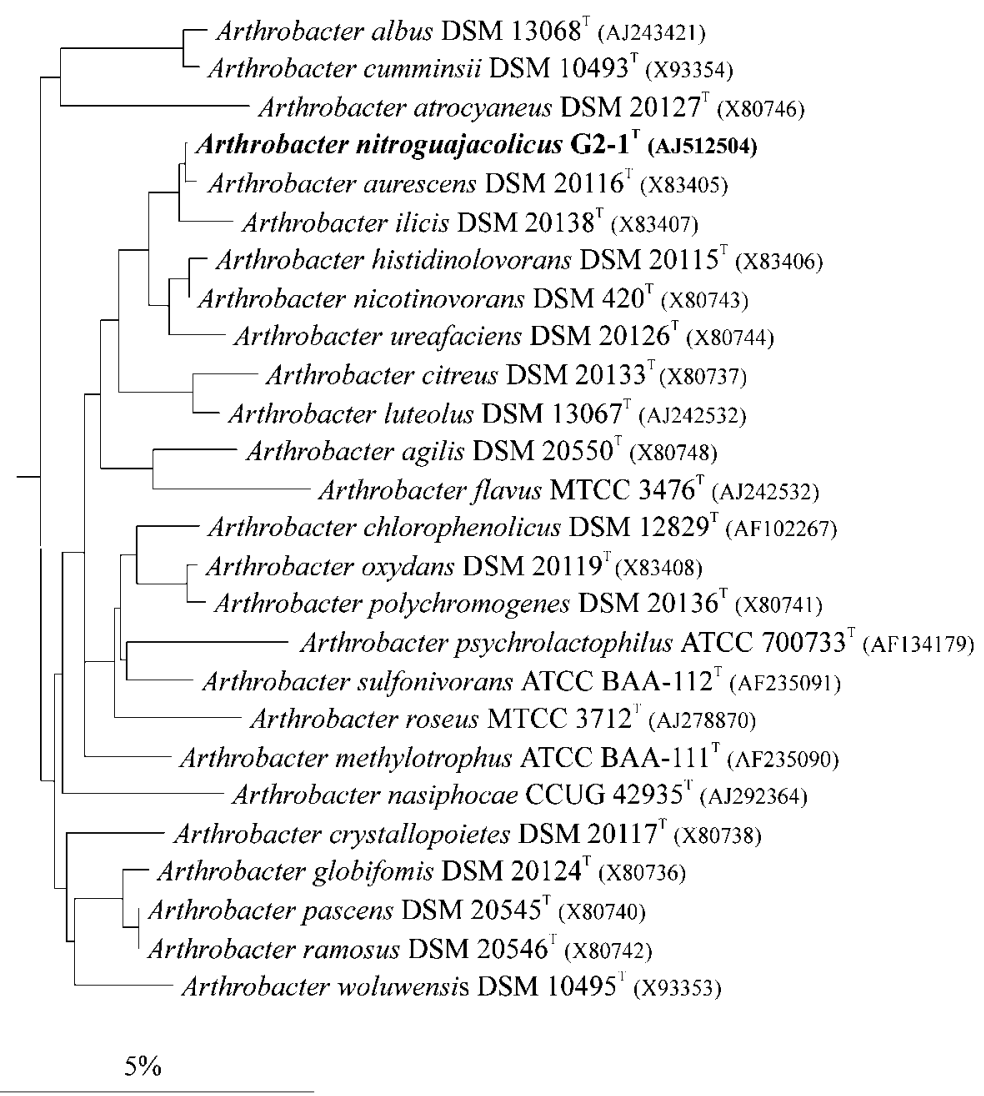

Fig. 1. Neighbour-joining tree for $16 \mathrm{~S}$ rRNA, showing the phylogenetic position of strain $\mathrm{G} 2-1^{\top}$ compared to other species of the genus Arthrobacter. Members of the Actinobacteria were used to root the dendrogram. The bar represents 5 substitutions per 100 nt.
Arthrobacter nicotinovorans (Stackebrandt \& Schumann, 2000) which also form a common phylogenetic group (Fig. 1).

Anteiso- $\mathrm{C}_{15: 0}$ was found to be the major fatty acid (65$70 \%$ ). Iso- $\mathrm{C}_{14: 0}$, iso- $\mathrm{C}_{15: 0}$, iso- $\mathrm{C}_{16: 0}$, anteiso- $\mathrm{C}_{17: 0}$ and some straight-chain saturated fatty acids $\left(\mathrm{C}_{14: 0}, \mathrm{C}_{16: 0}\right)$ were also present. The DNA base composition of strain $\mathrm{G} 2-1^{\mathrm{T}}$ was $61.9 \mathrm{~mol} \% \mathrm{G}+\mathrm{C}$. The fatty acid profile and DNA base composition are in agreement with data reported for other Arthrobacter species (Stackebrandt \& Schumann, $2000)$. The presence of isoH- $\mathrm{C}_{16: 1}(0 \cdot 8-0 \cdot 9 \%)$, anteiso$\mathrm{C}_{17: 1} \omega 9 c(0 \cdot 6-0 \cdot 8 \%)$ and $\mathrm{C}_{16: 1} \omega 7 c(1 \cdot 2-1 \cdot 3 \%)$ differentiates the isolates from the type strains of $A$. ilicis and A. aurescens. The fatty acid profiles are shown in Supplementary Table B in IJSEM Online.

Based on the results of phylogenetic analysis, riboprinting, DNA-DNA hybridization, and chemotaxonomic and physiological studies, it is proposed to classify the isolates

VCA $\mathrm{kb}$

VCC

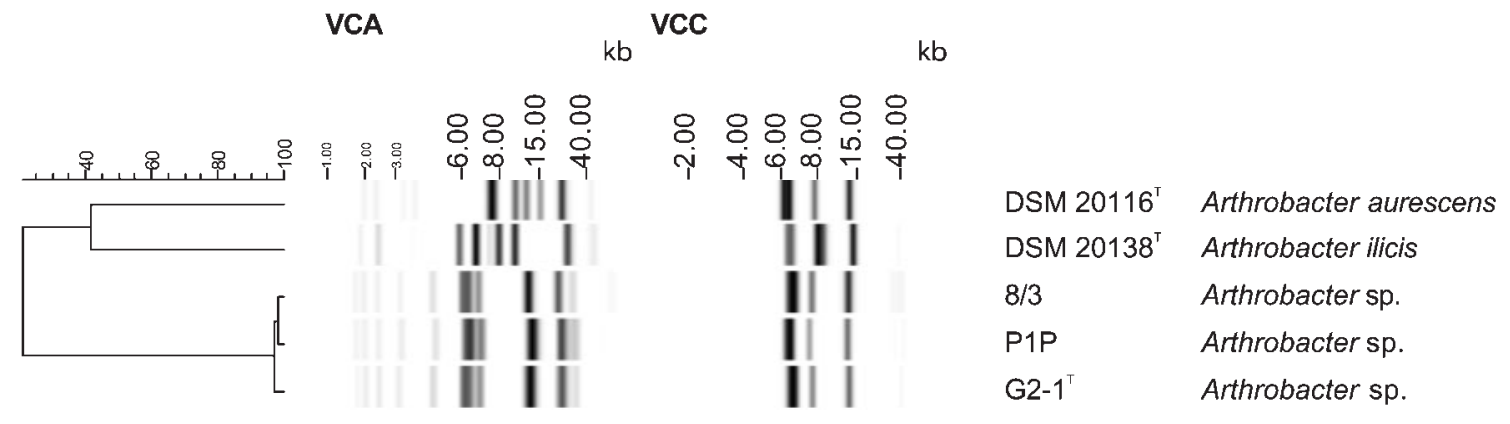

Fig. 2. Riboprint patterns generated by $E c o R I$ and $P$ vull for strains $\mathrm{G} 2-1^{\top}, \mathrm{P} 1 \mathrm{P}, 8 / 3$ and the type strains of $A$. aurescens and A. ilicis. VCA, Patterns obtained by EcoRI; VCC, patterns obtained by Pvull. The relationship dendrogram was calculated by BioNumerics software (Applied Maths). 
(a)

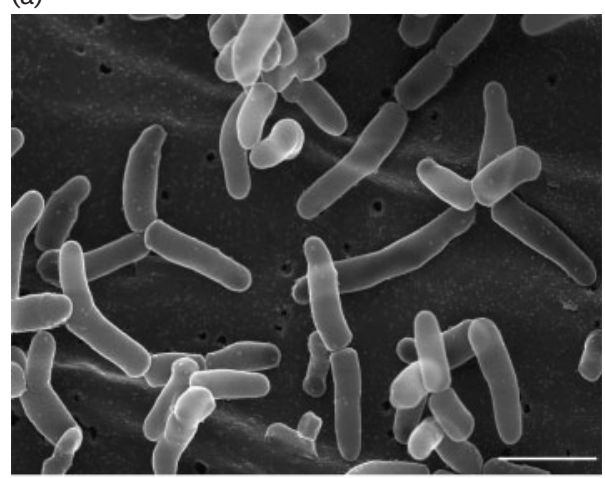

(b)

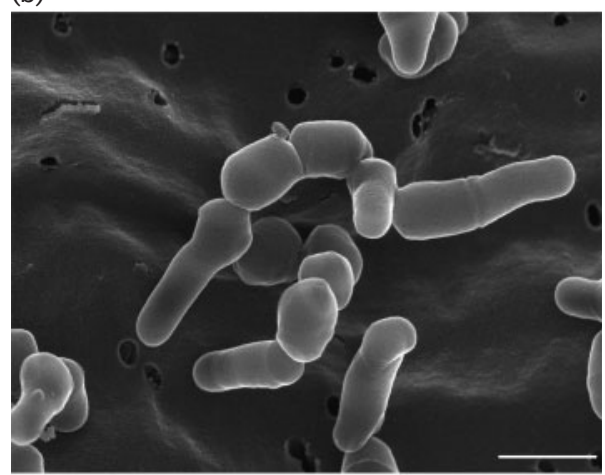

(c)

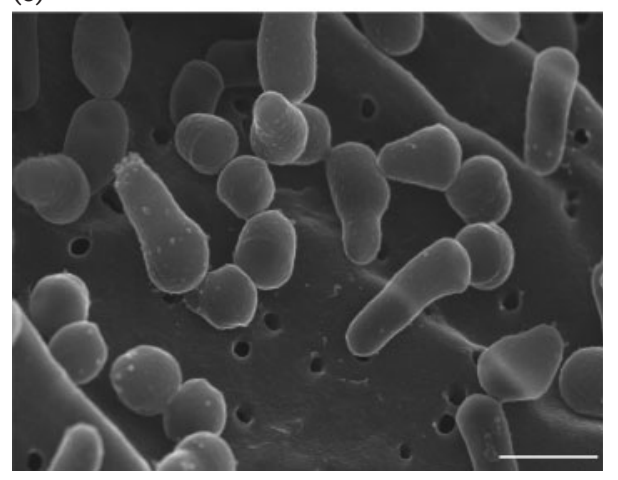

Fig. 3. Scanning electron micrographs of strains $\mathrm{G} 2-1^{\top}$ and $8 / 3$ grown in nutrient broth at $28^{\circ} \mathrm{C}$. (a) G2-1 ${ }^{\top}$ long rods after $8 \mathrm{~h}$ cultivation. Bar, $2 \mu \mathrm{m}$. (b) $\mathrm{G} 2-1^{\top}$ short rods, coccoid and clubshaped forms after $24 \mathrm{~h}$ cultivation. Bar, $1 \mu \mathrm{m}$. (c) Strain 8/3, coccoid and club-shaped forms after $24 \mathrm{~h}$ cultivation. Bar, $1 \mu \mathrm{m}$.

as representing a novel species, Arthrobacter nitroguajacolicus sp. nov., with the type strain $\mathrm{G} 2-1^{\mathrm{T}}$ (=CCM $4924^{\mathrm{T}}=$ DSM $15232^{\mathrm{T}}$ ).

\section{Description of Arthrobacter nitroguajacolicus sp. nov.}

Arthrobacter nitroguajacolicus (ni.tro.gu.a.ja.co'li.cus. N.L. masc. adj. nitroguajacolicus pertaining to the chemical nitroguaiacol, whose name is based on N.L. guaiacum from Spanish guayaco, a tropical American tree and the resin derived thereof).
Table 1. Differentiating characteristics of strain $\mathrm{G} 2-1^{\top}$ and type strains of $A$. aurescens and $A$. ilicis

Strains $\mathrm{P} 1 \mathrm{P}$ and $8 / 3$ correspond to $\mathrm{G} 2-1^{\mathrm{T}}$ in all characteristics except positive reaction for arbutin. $\mathrm{W}$, weakly positive reaction.

\begin{tabular}{|c|c|c|c|}
\hline Characteristic & G2-1 ${ }^{\mathrm{T}}$ & $\begin{array}{l}\text { A. aurescens } \\
\text { CCM } 1649^{\mathrm{T}}\end{array}$ & $\begin{array}{c}\text { A. ilicis } \\
\text { CCM } 4967^{\mathrm{T}}\end{array}$ \\
\hline Oxidase & + & + & - \\
\hline \multicolumn{4}{|l|}{ Hydrolysis of: } \\
\hline Aesculin & + & + & - \\
\hline Starch & + & + & - \\
\hline Elastase & + & + & - \\
\hline Pyrrolidonyl arylamidase & - & - & + \\
\hline Motility & + & - & + \\
\hline Utilization of gluconate & - & + & - \\
\hline \multicolumn{4}{|l|}{ Used for respiration: } \\
\hline D-Xylose & - & $\mathrm{W}$ & + \\
\hline Uridine & - & - & + \\
\hline Arbutin & $\mathrm{w}$ & $\mathrm{W}$ & - \\
\hline Sucrose & + & - & + \\
\hline Propionic acid & + & - & $\mathrm{W}$ \\
\hline$\alpha$-Cyclodextrin & - & + & - \\
\hline D-Melibiose & - & $\mathrm{W}$ & $\mathrm{w}$ \\
\hline 3-Methylglucose & - & $\mathrm{W}$ & $\mathrm{w}$ \\
\hline D-Raffinose & + & $\mathrm{W}$ & $\mathrm{W}$ \\
\hline Salicin & - & - & $\mathrm{W}$ \\
\hline
\end{tabular}

Cells are Gram-positive irregular rods, club-shaped with typical V-forms, motile and non-acid-fast. They display a rod-coccus life cycle. Cocci are $0 \cdot 7-1 \mu \mathrm{m}$ in diameter; rods are $0 \cdot 6-1 \cdot 0 \mu \mathrm{m}$ wide and $1 \cdot 0-4 \mu \mathrm{m}$ long. Spores are not formed. Colonies are yellow, circular, convex and opaque. Growth occurs with a suitable carbon source in mineral salts medium; no additional growth factors are required. Obligately aerobic. Growth at $4-37^{\circ} \mathrm{C}$, with optimum at $25-30{ }^{\circ} \mathrm{C}$. Growth occurs in the $\mathrm{pH}$ range $6 \cdot 0-8 \cdot 0$ and in the presence of up to $6 \%(\mathrm{w} / \mathrm{v}) \mathrm{NaCl}$. Catalase and oxidase positive. Nitrate not reduced. Methyl red test, urease and haemolysis negative. Gelatin, starch, casein, aesculin, ONPG and tyrosine are hydrolysed. Tween 80, DNA and lecithin are not hydrolysed. Elastase is produced. Pyrrolidonyl arylamidase and arginine dihydrolase are not produced. Production of alkaline phosphatase, acid phosphatase, $\alpha$ galactosidase and $\alpha$-fucosidase is variable between strains: the type strain shows positive reactions. Simmon's citrate is utilized, but not gluconate. Acid is not produced from ribose, mannitol, sorbitol, lactose, trehalose, raffinose, sucrose, L-arabinose, D-arabitol, cyclodextrin, glycogen, pullulan, maltose, melibiose, melezitose, methyl $\beta$-Dglucopyranoside or tagatose. In the Biolog test system, the following compounds are utilized for respiration: dextrin, glycogen, arbutin, D-cellobiose, D-fructose, D-galactose, $\alpha$-D-glucose, maltose, maltotriose, D-mannitol, D-mannose, palatinose, D-psicose, D-raffinose, D-ribose, D-sorbitol, sucrose, turanose, acetic acid, $\alpha$-hydroxybutyric acid, $\beta$ hydroxybutyric acid, p-hydroxyphenylacetic acid, L-malic 
acid, methyl pyruvate, propionic acid, pyruvic acid, alaninamide, D-alanine, L-alanine, L-alanyl-glycine, L-asparagine, L-glutamic acid, glycyl-L-glutamic acid, L-pyroglutamic acid, L-serine, putrescine and glycerol. Utilization of gentiobiose, $\alpha$-ketoglutaric acid and $\beta$-ketoglutaric acid is strain dependent: the type strain is positive. A negative reaction is seen with $\alpha$-cyclodextrin, $\beta$-cyclodextrin, inulin, mannan, Tween 40, Tween 80, $N$-acetyl-D-glucosamine, $N$ acetyl-D-mannosamine, amygdalin, L-arabinose, D-arabitol, L-fucose, D-galacturonic acid, $\alpha$-D-lactose, lactulose, Dmelezitose, D-melibiose, methyl $\alpha$-D-galactoside, methyl $\beta$-D-galactoside, 3 -methylglucose, methyl $\alpha$-D-glucoside, methyl $\beta$-D-glucoside, methyl $\alpha$-D-mannoside, L-rhamnose, salicin, sedoheptulosan, D-tagatose, D-trehalose, xylitol, D-xylose, $\gamma$-hydroxybutyric acid, lactamide, D-lactic acid methyl ester, D-malic acid, monomethyl succinate, succinamic acid, succinic acid, $N$-acetyl glutamic acid, 2,3-butanediol, adenosine, 2-deoxyadenosine, inosine, thymidine, uridine, adenosine $5^{\prime}$-monophosphate, thymidine $5^{\prime}$-monophosphate, uridine $5^{\prime}$-monophosphate, fructose 6-phosphate, glucose 1-phosphate, glucose 6-phosphate and DL- $\alpha$-glycerol phosphate. The cell wall diamino acid is lysine. The peptidoglycan type is A3 $\alpha$, with an Ala-ThrAla interpeptide bridge. The major menaquinone is MK$9\left(\mathrm{H}_{2}\right)$. The cellular fatty acid pattern is dominated by anteiso- $\mathrm{C}_{15: 0}$. The $\mathrm{G}+\mathrm{C}$ content is $61.9 \mathrm{~mol} \%$.

The type strain of Arthrobacter nitroguajacolicus is G2-1 $1^{\mathrm{T}}$ $\left(=\right.$ CCM $4924^{\mathrm{T}}=$ DSM $\left.15232^{\mathrm{T}}\right)$, isolated from forest soil.

\section{Acknowledgements}

We are grateful to N. Weiss, German Collection of Microorganisms and Cell Cultures, Braunschweig, Germany, for his interest, helpful suggestions and strain deposition. We also thank O. Benada and O. Kofronnová, Institute of Microbiology of the Academy of Sciences of the Czech Republic, Prague, for electron microscopy and Z. Páčová, Czech Collection of Microorganisms, Brno, for helpful discussions. We are grateful to $\mathrm{H}$. Trüper, University of Bonn, Germany, for his help with the Latin construction of the species epithet. This work was supported by the Grant Agency of the Czech Republic (postdoctoral project 204/00/P95) and by the Ministry of Education of the Czech Republic (project no. J07/98: 14310 0005).

\section{References}

Brosius, J., Palmer, M. L., Kennedy, J. P. \& Noller, H. F. (1978). Complete nucleotide sequence of a $16 \mathrm{~S}$ ribosomal RNA gene from Escherichia coli. Proc Natl Acad Sci U S A 75, 4801-4805.

Cashion, P., Hodder-Franklin, M. A., McCully, J. \& Franklin, M. (1977). A rapid method for the base ratio determination of bacterial DNA. Anal Biochem 81, 461-466.

Collins, M. D., Pirouz, T., Goodfellow, M. \& Minnikin, D. E. (1977). Distribution of menaquinones in actinomycetes and corynebacteria. J Gen Microbiol 100, 221-230.

Conn, H. J. \& Dimmick, I. (1947). Soil bacteria similar in morphology to Mycobacterium and Corynebacterium. J Bacteriol 54, 291-303.

De Soete, G. (1983). A least squares algorithm for fitting additive trees to proximity data. Psychometrika 48, 621-626.

DSMZ (2001). Catalogue of strains, 7th edn. Braunschweig: DSMZ.
Groth, I., Schumann, P., Weiss, N., Martin, K. \& Rainey, F. A. (1996). Agrococcus jenensis gen. nov., sp. nov., a new genus of actinomycetes with diaminobutyric acid in the cell wall. Int J Syst Bacteriol 46, 234-239.

Huß, V. A. R., Festl, H. \& Schleifer, K. H. (1983). Studies on the spectrophotometric determination of DNA hybridization from renaturation rates. Syst Appl Microbiol 4, 184-192.

Jahnke, K. D. (1992). Basic computer program for evaluation of spectroscopic DNA renaturation data from Gilford System 2600 spectrometer on a PC/XT/AT type personal computer. J Microbiol Methods 15, 61-73.

Jukes, T. H. \& Cantor, C. R. (1969). Evolution of protein molecules. In Mammalian Protein Metabolism, pp. 21-132. Edited by H. N. Munro. New York: Academic Press.

Koch, C., Schumann, P. \& Stackebrandt, E. (1995). Reclassification of Micrococcus agilis (Ali-Cohen 1889) to the genus Arthrobacter as Arthrobacter agilis comb. nov. and emendation of the genus Arthrobacter. Int J Syst Bacteriol 45, 837-839.

Kotoučková, L., Vavřik, J., Němec, M., Plocek, J. \& Zdráhal, Z. (1997). Use of immobilized cells of the strain Corynebacterium sp. for 4-nitrophenol degradation. Folia Microbiol 42, 509-512.

Maidak, B. L., Cole, J. R., Parker, C. T., Jr \& 11 other authors (1999). A new version of the RDP (Ribosomal Database Project). Nucleic Acids Res 27, 171-173.

Mesbah, M., Premachandran, U. \& Whitman, W. B. (1989). Precise measurement of the $\mathrm{G}+\mathrm{C}$ content of deoxyribonucleic acid by high-performance liquid chromatography. Int J Syst Bacteriol 39, 159-167.

M. I. D. I., Inc. (1999). Sherlock, Microbial Identification System, operating manual, version 3.0. Newark, DE: MIDI, Inc.

Pospíšil, S., Benada, O., Kofroňová, O., Petřiček, M., Janda, L. \& Havlíček, V. (1998). Kytococcus sedentarius (formerly Micrococcus sedentarius) and Dermacoccus nishinomiyaensis (formerly Micrococcus nishinomiyaensis) produce monensins, typical Streptomyces cinnamonensis metabolites. Can J Microbiol 44, 1007-1011.

Rainey, F. A., Ward-Rainey, N., Kroppenstedt, R. M. \& Stackebrandt, E. (1996). The genus Nocardiopsis represents a phylogenetically coherent taxon and a distinct actinomycete lineage: proposal of Nocardiopsaceae fam. nov. Int J Syst Bacteriol 46, 1088-1092.

Schleifer, K. H. (1985). Analysis of the chemical composition and primary structure of murein. Methods Microbiol 18, 123-156.

Schleifer, K. H. \& Kandler, O. (1972). Peptidoglycan types of bacterial cell walls and their taxonomic implications. Bacteriol Rev 36, 407-477.

Smibert, R. M. \& Krieg, N. R. (1994). Phenotypic characterization. In Methods for General and Molecular Bacteriology, pp. 607-654. Edited by P. Gerhardt. Washington, DC: American Society for Microbiology.

Stackebrandt, E. \& Schumann, P. (2000). Introduction to the taxonomy of actinobacteria. In The Prokaryotes: an Evolving Electronic Resource for the Microbiological Community, 3rd edn, release 3.3, August 9. Springer: New York. (http://link.springer-ny. com/link/service/books/10125/).

Wayne, L. G., Brenner, D. J., Colwell, R. R. \& 9 other authors (1987). International Committee on Systematic Bacteriology. Report of the ad hoc committee on reconciliation of approaches to bacterial systematics. Int J Syst Bacteriol 37, 463-464.

Westerberg, K., Elväng, A. M., Stackebrandt, E. \& Jansson, J. K. (2000). Arthrobacter chlorophenolicus sp. nov., a new species capable of degrading high concentrations of 4-chlorophenol. Int J Syst Evol Microbiol 50, 2083-2092. 